\title{
Respiratory symptoms in older people and use of domestic gas appliances
}

\author{
L Dow, L Phelps, L Fowler, K Waters, D Coggon, S T Holgate
}

Care of the Elderly, Division of Medicine, Bristol University

L Dow

L Phelps

L Fowler

NHS R\&D Support

Unit, Frenchay

Healthcare Trust

K Waters

MRC Environmental

Epidemiology Unit,

University of

Southampton

D Coggon

University Medicine, University of

Southampton

$S$ T Holgate

Correspondence to:

Dr L Dow, Care of the

Elderly, Frenchay Hospital,

Bristol BS16 1LE, UK

Received 8 March 1999

Returned to authors

15 April 1999

Revised manuscript received

16 June 1999

Accepted for publication

28 June 1999

\begin{abstract}
Background-Studies in children and young women have indicated an increased risk of respiratory illness in association with the use of domestic gas appliances, possibly caused by oxides of nitrogen generated when gas is burned. It is not known whether risks are similarly increased in older subjects.

Methods-A questionnaire about respiratory symptoms in the past year and potential risk factors for respiratory disease was mailed to 6000 men and women aged 65 years and older who were selected at random from the lists of general practices in North Bristol, UK. Associations between symptoms and the use of gas appliances were examined by logistic regression with adjustment for age, sex, social class, and smoking habits.
\end{abstract}

Results-Questionnaires were completed by $4792(80 \%)$ of those mailed. The most common symptoms were exercise induced breathlessness, wheeze, or chest tightness (51\%); wheeze (27\%); morning phlegm $(20 \%)$; and daytime breathlessness at rest (19\%). In an analysis that included all subjects only weak associations were found with use of gas appliances, odds ratios all being 1.2 or less. The risks associated with use of a gas hob tended to be higher in women, with odds ratios of 1.36 $(95 \%$ CI 1.01 to 1.83$)$ for wheeze and 1.33 (95\% CI 0.56 to 3.17 ) for morning chest tightness, but were lower than had been reported previously in younger women. Conclusion-The absence of stronger associations cannot readily be explained by bias or confounding. Gas cookers and fires are unlikely to be an important cause of respiratory illness in the elderly. If they do cause such illness, the largest risks are likely to be in women who use gas hobs. (Thorax 1999;54:1104-1106)

Keywords: gas cooking; respiratory disease

Respiratory symptoms are common in the elderly and often occur as a consequence of underlying asthma or chronic obstructive pulmonary disease. Some studies in children have indicated that the use of domestic gas appliances is associated with an increased frequency of respiratory illness, perhaps caused by oxides of nitrogen generated when gas is burned. In 1992 a meta-analysis of such investigations found that a long term increase in exposure to nitrogen dioxide, similar to that which would be expected from use of a gas stove in the home, was associated with approximately $20 \%$ higher odds of respiratory illness. ${ }^{1}$ More recently, however, a British survey of more than 25000 children suggested that any risks associated with the presence of a gas cooker in the home were much smaller than this. ${ }^{2}$ Some studies in adults have also linked the use of gas appliances to a higher prevalence of respiratory symptoms, ${ }^{3-5}$ although again the observation has not been entirely consistent. ${ }^{6}$ In one study symptoms were associated with use of a gas stove in young women but not men, and the authors speculated that this may have been because women spend more time cooking than men. ${ }^{5}$ In another survey the association was confined to men. ${ }^{3}$

So far there have been no published studies of the relation between use of gas appliances and respiratory morbidity in older people. We have investigated this question as part of a cross sectional survey of respiratory disease in elderly residents of Bristol and neighbouring districts.

\section{Methods}

Six thousand subjects were selected from the computerised lists of 21 general practices covering inner city, suburban, and rural areas in and around North Bristol. A stratified random sampling method was used to obtain approximately equal numbers of men and women in the age ranges $65-74$ years and 75 years and older.

Each subject was sent a postal questionnaire with a covering letter signed by his or her general practitioner and by the study investigators (LD, LP, LF). The questionnaire, which had been used in an earlier community survey of the elderly elsewhere, ${ }^{7}$ asked about respiratory symptoms over the last year. These symptoms are listed in table 1 . The section of the inquiry relating to wheeze, breathlessness, and phlegm was taken from a questionnaire developed by the Department of Community Medicine at St Thomas' Hospital, whilst the questions about morning chest tightness and bronchial irritability were adapted from those used by Mortagy et 
Table 1 Prevalence of respiratory symptoms in past year and association with use of gas appliances

\begin{tabular}{|c|c|c|c|c|}
\hline Symptom & $\begin{array}{l}\text { Prevalence } \\
(\%) \text { in those } \\
\text { who answered } \\
\text { question* }\end{array}$ & Gas hob OR $(95 \% \mathrm{Cl})$ & Gas oven $O R(95 \% \mathrm{Cl})$ & Gas fire OR $(95 \% \mathrm{Cl})$ \\
\hline Wheeze & 27 & $1.18(0.98$ to 1.43$)$ & $1.02(0.87$ to 1.19$)$ & $0.98(0.84$ to 1.15$)$ \\
\hline Daytime breathlessness at rest & 19 & $1.11(0.90$ to 1.38$)$ & 0.93 (0.77 to 1.12$)$ & $0.93(0.78$ to 1.11$)$ \\
\hline Woken at night by breathlessness & 10 & $0.98(0.74$ to 1.31$)$ & $1.00(0.79$ to 1.28$)$ & $1.05(0.83$ to 1.32$)$ \\
\hline Chest tightness for an hour or longer in the morning on waking & 3 & $1.17(0.69$ to 1.96$)$ & $0.81(0.51$ to 1.29$)$ & $0.95(0.62$ to 1.46$)$ \\
\hline Usually bring up phlegm from chest first thing in the morning & 20 & $0.97(0.78$ to 1.20$)$ & $1.07(0.90$ to 1.28$)$ & $0.99(0.83$ to 1.17$)$ \\
\hline One or more colds gone to chest & 34 & $1.20(1.01$ to 1.43$)$ & $1.04(0.90$ to 1.21$)$ & $1.02(0.89$ to 1.18$)$ \\
\hline \multicolumn{5}{|l|}{ Breathlessness, wheeze, or chest tightness induced by going } \\
\hline & 19 & $1.18(0.96$ to 1.44$)$ & $1.04(0.88$ to 1.24$)$ & $1.02(0.86$ to 1.20$)$ \\
\hline Breathlessness, wheeze, or chest tightness induced by going & 31 & $1.12(0.95$ to 1.32$)$ & $1.17(1.02$ to 1.34$)$ & $1.02(0.90101 .11)$ \\
\hline into a smoky room & 21 & $1.11(0.91$ to 1.35$)$ & 1.05 (0.89 to 1.25$)$ & 1.05 (0.89 to 1.24$)$ \\
\hline $\begin{array}{l}\text { Breathlessness, wheeze, or chest tightness induced by going } \\
\text { into a room where the air was full of dust }\end{array}$ & 18 & $1.02(0.83$ to 1.27$)$ & $1.07(0.90$ to 1.28$)$ & $0.97(0.82$ to 1.15$)$ \\
\hline
\end{tabular}

${ }^{\star}$ Information about individual symptoms was missing for up to 296 subjects.

Associations with each type of gas appliance were examined in separate regression models with adjustment for sex, age, social class, and smoking habits.

al. ${ }^{8}$ In addition, subjects were asked about their use of gas appliances within the home ("Do you use a gas hob?", "Do you use a gas oven or stove?", "Do you use a gas fire?"), smoking habits and last full time occupation (or, for married women, that of their husband). The last information was used to classify subjects by social class. Non-responders were sent a reminder after four weeks.

Multiple logistic regression was used to analyse the association between respiratory symptoms and use of different domestic gas appliances whilst controlling for the possible confounding effects of age (65-74, 75 and older), sex, social class (four strata), and smoking habits (current smoker, ex-smoker, nonsmoker).

\section{Results}

Replies were received from $4792(80 \%)$ of the 6000 subjects mailed. Their ages ranged from 65 to 104 years; 2433 (51\%) were men and $2904(61 \%)$ reported using one or more gas appliances in their home. They were distributed fairly evenly across the social classes $(24.8 \%$ in classes I and II; $17.0 \%$ in classes IV and $\mathrm{V}$ ), and most were ex-smokers $(45.4 \%)$ or had never smoked (38.5\%).

Table 1 shows the prevalence of respiratory symptoms and their association with use of gas appliances in an analysis that included both men and women. The most frequently reported symptoms were exercise induced breathlessness, wheeze, or chest tightness (51\%); wheeze $(27 \%)$; morning phlegm $(20 \%)$; and daytime breathlessness at rest (19\%). Symptoms were more common at older ages, in social classes IV and V, and in current and ex-smokers. After adjustment for potential confounders only weak associations were found with use of gas appliances, all odds ratios being 1.2 or less. Two were statistically significant at a 5\% level (a cold going to the chest with use of a gas hob, and exercise induced breathlessness, wheeze or chest tightness with use of a gas oven). There was no consistent trend to higher risks among the 457 $(10 \%)$ subjects who reported use of all three appliances.

When similar analyses were carried out for men and women separately, differences in the associations with use of gas ovens and fires were unremarkable. However, the risks associated with use of a gas hob tended to be higher in women than in men (table 2). The highest risks in women were for wheeze (OR 1.36, 95\% CI 1.01 to 1.83 ) and for morning chest tightness (OR $1.33,95 \%$ CI 0.56 to 3.17 ).

\section{Discussion}

In this cross sectional survey of elderly people from the general population we found little

Table 2 Associations of respiratory symptoms in past year with use of a gas hob in men and women

\begin{tabular}{|c|c|c|c|c|}
\hline \multirow[b]{2}{*}{ Symptom } & \multicolumn{2}{|l|}{ Men } & \multicolumn{2}{|l|}{ Women } \\
\hline & $\begin{array}{l}\text { Prevalence (\%) in } \\
\text { those with a gas hob }\end{array}$ & OR $(95 \% \mathrm{Cl})$ & $\begin{array}{l}\text { Prevalence (\%) in } \\
\text { those with a gas hob }\end{array}$ & OR $(95 \% \mathrm{Cl})$ \\
\hline Wheeze & 30 & 1.07 (0.83 to 1.37$)$ & 26 & $1.36(1.01$ to 1.83$)$ \\
\hline Daytime breathlessness at rest & 18 & $1.08(0.81$ to 1.44$)$ & 20 & $1.17(0.85$ to 1.62$)$ \\
\hline Woken at night by breathlessness & 9 & $0.87(0.59$ to 1.28$)$ & 10 & $1.16(0.75$ to 1.80$)$ \\
\hline $\begin{array}{l}\text { Chest tightness for an hour or longer } \\
\text { in the morning on waking }\end{array}$ & 3 & $1.09(0.57$ to 2.10$)$ & 2 & $1.33(0.56$ to 3.17$)$ \\
\hline $\begin{array}{l}\text { Usually bring up phlegm from chest } \\
\text { first thing in the morning }\end{array}$ & 23 & 0.85 (0.65 to 1.12$)$ & 15 & $1.24(0.86$ to 1.77$)$ \\
\hline One or more colds gone to chest & 38 & $1.17(0.93$ to 1.48$)$ & 35 & $1.23(0.95$ to 1.61$)$ \\
\hline $\begin{array}{l}\text { Breathlessness, wheeze, or chest } \\
\text { tightness induced by going from } \\
\text { a warm room into cold air }\end{array}$ & 22 & $1.15(0.88$ to 1.50$)$ & 18 & $1.21(0.88$ to 1.68$)$ \\
\hline $\begin{array}{l}\text { Breathlessness, wheeze, or chest } \\
\text { tightness induced by exercise }\end{array}$ & 52 & $1.14(0.92$ to 1.42$)$ & 53 & $1.11(0.86$ to 1.43$)$ \\
\hline $\begin{array}{l}\text { Breathlessness, wheeze, or chest } \\
\text { tightness induced by going into } \\
\text { a smoky room }\end{array}$ & 21 & 1.07 (0.82 to 1.39$)$ & 21 & $1.18(0.87$ to 1.61$)$ \\
\hline $\begin{array}{l}\text { Breathlessness, wheeze, or chest } \\
\text { tightness induced by going into a } \\
\text { room where the air was full of dust }\end{array}$ & 20 & $0.96(0.73$ to 1.27$)$ & 16 & $1.13(0.81$ to 1.59$)$ \\
\hline
\end{tabular}

Associations were adjusted for age, social class, and smoking habits. 
evidence that the prevalence of respiratory symptoms was influenced to a significant extent by the use of domestic gas appliances. In analyses for both sexes combined the odds ratios were all 1.2 or lower, and only two of the 30 that we calculated were statistically significant at the 5\% level. These are smaller than the risks reported from some studies in children ${ }^{1}$ and younger adults. $^{3-5}$ Like Jarvis and colleagues, ${ }^{5}$ we found that associations with use of a gas hob were stronger in women than in men. However, even the highest risk in women, an OR of 1.36 for wheeze, was much lower than those reported by Jarvis.

The lower levels of risk in our study are unlikely to have arisen from biases in the selection of the study sample. The response rate was high $(80 \%)$ and there is no reason to suspect that the relation between symptoms and use of gas appliances would differ materially in non-responders as compared with those who answered the questionnaire. By definition, all subjects had survived to age 65 and, if gas combustion products were a major cause of respiratory illness, it is possible that some susceptible individuals would die before reaching this age. However, if exposure had any important effect on mortality at younger ages, we would expect to see stronger associations with morbidity among survivors.

We did not attempt to validate the symptoms reported but, in an earlier study using the same questionnaire in another sample of elderly people from the general population, there was a good correlation between symptoms and abnormalities of lung function. ${ }^{9}$ Nor did we collect any information about the extent to which individual subjects used their gas appliances. However, older people generally spend more time in their homes than children and young adults, which would tend to increase their cumulative exposure to gas combustion products.
Of the known determinants of respiratory disease that might confound associations with the use of gas appliances, smoking and factors related to social class are the most important. Risk estimates were adjusted for these variables. Moreover, the unadjusted odds ratios (not presented) were little different, making it unlikely that the failure to demonstrate stronger associations could be explained by residual confounding.

We conclude that the absence of clear associations between respiratory symptoms and use of gas appliances in our study cannot readily be explained by bias or confounding, and that use of gas cookers and fires is unlikely to be an important cause of respiratory illness in the elderly. If they do cause such illness, the largest risks are likely to be in women who use gas hobs.

This study was funded by the Wellcome Trust. The authors would also like to thank the participants and the North Bristol general practices.

1 Hasselblad V, Eddy DM, Kotchmar DJ. Synthesis of environmental evidence: nitrogen dioxide epidemiology studies. F Air Waste Management Assoc 1992;42:662-71.

2 Burr ML, Anderson HR, Austin JB, et al. Respiratory symptoms and home environment in children: a national survey. Thorax 1999;54:27-32.

3 Comstock G, Meyer M, Helsing K, et al. Respiratory effects of household exposures to tobacco smoke and gas cooking. Am Rev Respir Dis 1981;124:143-8.

$4 \mathrm{Ng}$ TP, Hui KP, Tan WC. Respiratory symptoms and lung function effects of domestic exposure to tobacco smoke function effects of domestic exposure to tobacco smoke and cooking by gas in non-smoking women in

5 Jarvis D, Chinn S, Luczynska C, et al. Association of respiratory symptoms and lung function in young adults with use of gas appliances. Lancet 1996;344:1733-6.

6 Keller MID, Lanese RR, Mitchell R, et al. Respiratory illness in households using gas and electricity for cooking. Environ Res 1979;19:495-503.

7 Dow L, Coggon D, Osmond C, et al. A population survey of respiratory symptoms in the elderly. Eur Respir f 1991;4: 267-72.

8 Mortagy AK, Howell JBL, Waters WE. Respiratory symptoms and bronchial reactivity: identification of a syndrome and its relation to asthma. BMf 1986;293:525-9.

9 Dow L, Coggon D, Holgate ST. Respiratory symptoms as predictors of airways lability in an elderly population. Respir Med 1992;86:27-32. 